\title{
ポーランドの地理学
}

山本茂*

\section{Geography of Poland}

Shigeru YAMAMOTO*

\begin{abstract}
Aim: The author describes the main characteristics of the study of geography sciences in Poland and its development. In Poland, the continuity of geography sciences has fairly strong foundations. To explain these foundations the author discusses the relationship between the history of geography sciences in Poland and research since the 18th century, as well as the importance of knowledge about the country's land, people, and history.

Method: Three approaches are adopted in this study. Interviews and discussions with geographers in Poland helped to enhance the author's understanding. The standard research method of collecting and reading literature was used; however, knowledge obtained through observations during the author' stay in Poland over the past 40 years was another important source of information used to complete this study.

Results: The main results can be summarized by three points.

1. Poland's geography is important from a geopolitical viewpoint.

2. The Academy of Sciences systems introduced along with socialism can be regarded as a device that supports geography sciences.

3. Five major accomplishments are identified in geography science research in Poland.

(1) Progress of theory in economic geography from the 1950s into the $1990 \mathrm{~s}$ : the theory and practice of economic regionalization.

(2) Studies in urban and population geography conducted from the 1960s into the 1990s.

(3) Studies in the regional (spatial) structure of national economy and, as an extension, the development of socialist futurology (or geography of the future) toward the 21st century.

(4) Restoration of traditional regional geography in forms such as the study of ethnic minority groups in the Eurasian space. Eastern border problems in the EU, Republic of Poland, and ethnic minorities.

(5) Cartography: the national atlases published during these periods were notable achievements in the field of cartography.
\end{abstract}

Key words : Poland, geography sciences, department of geography, geopolitical location, “Academy of Sciences” systems, regional (spatial) structure of national economy, urban agglomeration

キーワード : ポーランド, 地理学, 地理学教室, 地政学的位置, 科学アカデミー・システム, 国民 経済の地域構造, 大都市圈

* 埼玉大学名誉教授

* Professor Emeritus, Saitama University, Saitama, 338-8570, Japan 


\section{I.はじめに}

本稿の目的はポーランドの地理学研究の特質を 国際的視点，とくに日本との比較において説明す ることにある。

第一にいえることは，ポーランドにおいて地理 学が諸科学のなかで基本的なディシプリンとし て, 学術研究にも社会的にもしっかりと根付いて いることである。地理学はポーランド社会で二つ の側面で認知されている。一つはあらゆるレベル の学校教育における独立教科として，中等教育で は地理は全員が履修しており，とりわけ高等教育 の社会科学系分野においては卒業要件のひとつと 位置づけられている。この点で中等教育（後期） における地理履修率が半数にも満たない日本の状 況とはきわめて対照的である。

二つ目に地理学研究の成果とその社会的応用 · 実践的役割においてである。ポーランドにおける 地理（学）の立ち位置は, 長い歴史と伝統のなか で構築されてきたものであって，第二次世界大戦 の戦禍をくぐり，半世紀にわたる社会主義時代を 経て，はたまた市場経済体制下にあっても，なお 安定的であり普遍的な存在である。

本稿では，われわれの手が届く，しかも実際的 に多少の意味が感じられる現代，とくに第二次世 界大戦後の社会主義時代および 1989 年以降の市 場経済移行期（それぞれ時代名称には多くの可能 性がある）の四半世紀におけるポーランド地理学 の問題性について言及するに留める。

ポーランド社会の歴史的転換期に遭遇して地理 学界が地理学研究の来し方と行く末について内在 的な反省と問題点の整理に向かうのは自然のこと である。近年, その営みの代表的な成果が公刊さ れ (Jackowski et al., 2008)，またこれまでにも時 どきの論文として発表されてきた（Taylor, 1985; Rykiel, 1988; Chojnicki, 1996; Kortus, 2001)。

だがこの国の地理学の現状と問題性について, 日本語で書かれた記述はほぼ皆無であり, 執筆者 がこの分野についてほとんど関心がなかったにも かかわらず素描を試みるのも多少の意味を感じる からである。とくに 1970 年代前半（ギエレク時
代）からこの国の地理学の環境に身を置いてきた 立場から経験的な観察も含めてたどってみるが, 限られた観察力で思わ㛣りがあればご海容をい ただきたい。

\section{II. 研究教育体制, 学会活動, 大学院教育・学部教育}

本章では, この国の地理学界を特徵づける科学 アカデミー制度について概説し, ついで学会活 動, 大学院教育 (研究者養成), 学部教育, 中等 教育, それらの変化に分けて考察する。

\section{1）科学アカデミー制度と高等教育}

\section{1-1）科学アカデミーの制度と組織}

ポーランドにおける科学アカデミーと大学の関 係について，わかりにくいところではあるが，正し く理解しておく必要がある。ポーランドと日本の 地理学界において大きく相違している点は, 科学 アカデミーの存在と大学・大学院との関係である。

科学アカデミーの制度と組織は 1950 年代初頭 にソ連・東欧諸国で国の最高レベルの研究機関と して創設された。ポーランドを含むほぼすべての 国ぐにで相次いで整備されていった。ポーランド において科学アカデミー制度は 1952 年に導入さ れ, ポーランド科学アカデミー地理学研究所 (Instytut Geografii, Polskie Akademia Nauk, 以 下 IG PAN と略記）は 1953 年にスタニスワフ・ レシチツキ（S. Leszczycki, 1907-1996）を初代 所長に迎えて発足した。レシチツキはクラクフ出 身の地理学者で, ナチス侵略時にヤギェオ大学教 授団 300 人の一員としてミュンヘン近郊のダッ ハウ収容所に連行され，その地で終戦を迎えた。 戦後帰国してクラクフで大学教員に戻るが，ポー ランド社会の復興とワルシャワ大学の再建のため ワルシャワ大学に転じ, 1948 年から地理学研究 所長の職に就いた。

1953 年には IG PAN とワルシャワ大学地理学 部 (Institute Gografii, Uniwersytet Warszawski, 以下 IG UW と略記）というポーランド最大の 2 つの地理学研究・教育機関の長を兼務してポーラ ンド地理学界に大きな権力をふるうことになっ た。その在任期間は実に 30 年に及んだ。ちなみ 
にレシチツキはポーランド統一労働者党 (PZPR) 党員であり，その活動範囲はアカデミズムの地理 学者であるに留まらず，ポーランド外務省の第一 外務次官として, 戦後ソ連に割譲された旧東部領 から数 100 万人の住民の引揚とその定着事業の 責任者として大きな貢献をした。

ポーランドの戦後権力はソ連型集権制とは異な り，たとえば大学・学部などで正副学部長（2 4 人）のうち最低 1 人は党員でなければならない という指導と暗黙の了解のもとで大学の自治と自 由は相対的に保たれていた。これは実証不可能だ が，平時の安定装置としては妥当な指針であった と思われる。

レシチツキは地理学者としては経済地理学分野 で活動し，国民経済の地域構造の解明，地理学方 法論の探求, 観光地理学の創始など戦後ポーラン ド地理学の創設と発展に大いに貢献した。また国 際地理学連合 (IGU) の会長 (1968-1972), 副 会長（1972-1976）やその経済地理コミッション 委員長などの要職を歴任している。

退官時にはワルシャワ大学で 3 人目となる「桂 冠教授」(Laureate Professor) の称号を授与さ れ，また従来の IG PAN のほうは正式名称を「ス タニスワフ・レシチツキ記念地理学・空間経営研 究所」(IGiPZ PAN と略記) と改め, その偉業を 讃えている。

1-2）ポーランド科学アカデミー地理科学委員会 この IGiPZ PAN の存立基盤はどこに求められ るか。ポーランド科学アカデミーは学問のディシ プリンごとに数多くの委員会 (Commission) が 組織されている。そのなかで地理学研究・教育を 担当する組織は,「ポーランド科学アカデミー地 理科学委員会」(Commission on Geographical Sciences）である。

この委員会がポーランド国内の地理学研究と教 育全般について責任を負うことになっている。委 員会のメンバーは 30 ～ 40 人で, 全国の教授・ 准教授から秘密投票で選出され，一定期間（3 4 年), その任務にたずさわる。ここでは出身大 学や特定グループの互選というような恣意性は機 能せず，社会的公正が保たれている。50 年に及
ぶ科学アカデミー地理科学委員会の歴史のなか でレシチッキは 14 年にわたり会長職を務め, 地理学界全体の発展の推進力となっていた。

IGiPZ PAN は，この委員会に対して，国民経 済にとってとくに高度な研究を遂行すること，全 国の大学など他の地理学研究センターとの共同研 究やその成果に対する出版助成などを通して責任 を果たすことになっている。

国民の負託を負ったこの委員会が研究課題を果 たすためには中長期的な人事政策が求められる。 IGiPZ PAN は他のいずれの大学や研究機関より も優れた研究スタッフ (人材), 研究施設, 研究 費などが与えられ，1989 年以降は，際立った特 権的地位 (“Primus inter pares”) を付与され, ポーランドで最重要な地理学研究センターとして 役割を果たすよう強く求められている。

IGiPZ PAN はポーランド語による代表的学術誌 として “Przegląd Geograficzny” (地理学評論) を 季刊で刊行している。英文誌として“Geographia Polonica”, “Geopolitical Studies”, “EUROPA XX1”を刊行している。他に“Prace Geograficzne”, “Atlas Warszawy”なども上梓されている。

\section{2）地理学会の活動}

\section{2-1) IGiPZ PAN と PTG}

ポーランド地理学界における学会活動を日本の 場合と対比しながら考えてみる。ポーランドの地 理学は多くのヨーロッパ諸国の例に伍して, 地理 学の社会的位置および国民教養の基礎的分野とし て高度な制度化がされていて，しっかり定着して いる。それは日本の地理学界とはまず対照的な立 場にあるといえる。

IGiPZ PAN は地理学研究の中心的存在ではあ るが，それ自体は地理学会ではない。ポーランド で地理学会といえばまず「ポーランド地理学協 会」(Polskie Towarzystwo Geograficzne, PTG) で, 会員数約 1,500 人 $(2006)$, 各地に 23 支部 を置いている。同会は新生ポーランド成立期の 1918 年に設立され，第二次世界大戦時を除いて 年 1 回の全国大会を開催している。その参加者 数は他の学会のなかで最大規模である。年次大会 は各支部持ち回りで開催されている。 
PTG 会員は大学教員や研究機関の専門研究者, 中等教育の教員，地理愛好者，技術者などからな る。社会主義時代，学会活動の財政は国家予算で 維持されていた。会員数は，2,500人 (1956) 3,418 人 (1978) と不安定で変動が激しい。市場経 済移行に伴う混乱期にはわずか 1,000 人（1995） に落ち込んだこともあった。

機関誌『地理学雑誌』(Czasopismo Geograficzne) はポーランド最古の地理学誌の一つで, 協 会の本部はワルシャワ大学地理学部の一室におか れ，IGiPZ PAN のバンスキ（J. Bański）が会長 職に就いている。

そのほか協会以外にも各地の大学に関連する学 会や専門分野別の研究部会のシンポジウムなどが 組織されており，そのなかには世界レベルの専門 学会に成長したものもある（Zioło, 2010）。

だが，日本のように全国的総合的な学会が年次 大会を開催しそこに多くの学会員が参加したり, 専門分野別にも全国的学会があり，そこにもかな りの学会員が参集したり，同時に地域的ブロック 的の学会もあって，かなりの学会員が参加する研 究大会が開催されるというある種の“賑わい”と いうものはない。むしろ，各学協会や IGiPZ PAN のような研究センターで頻繁に開催される研究集 会や分野ごとのセミナーなどが実質的な研究発表 と交流の場となっている。

一般的には各種研究集会を渡り歩くことも多く ないし，研究集会が時期的に集中することもない ようだ。

『地理学雑誌』と並んで，ポーランド地理学界 でもっとも権威の高い研究誌に『地理学評論』 (Przeglad Geograficzny) がある。後者はポーラ ンド地理学協会が設立された 1918 年以来，同協 会の公式出版物であったが，第二次世界大戦後に IG PAN が創設されると，その機関誌となり現在 に至っている。

かわって，ポーランド地理学協会はそれまで ポーランド地理教員連盟（Zrzeszenie Polskich Nauczycieli Geografii）の機関誌であった出版物 を PTGの機関誌『地理学雑誌』(Czasopismo Geograficzne) として継承することになった。

\section{2-2）ポーランド地理学界とヨーロッパ}

ポーランド地理学界のヨーロッパ諸国との交流 は 19 世紀末にさかのぼるが，国際地理学連合第 7 回大会（ベルリン）の参加者名簿にはポーラン ド地理学者の名前が記帳されている。またポーラ ンドが独立を回復した 1918 年には国土への地理 的関心の高まりのなかでワルシャワおよびクラク フの大学教授らによって研究成果が結実し, 1922 年の第 8 回大会（ブリュッセル）では新生 ポーランドから E. ロメル（ルヴフ, 1871-1954） の主唱で一連の報告書が提出された。1928 年に はロメルは東中欧で最初の IGU 副会長のポスト に就いた。

第二次世界大戦の帰結として，ヨーロッパは東 西に分裂し，ポーランドは社会主義国となった。 第二次世界大戦後, ポーランド地理学界が IGC に代表団を送ったのは第 18 回大会（リオデジャ ネイロ）であった。ポーランドはそれ以降毎回 IGC に代表団を派遣して地理学研究の発展に貢 献してきた。

この 60 年の期間に，ポーランドの地理学者が IGU 会長に就いたのは，スタニスワフ・レシチッ キ（1968-1972），副会長には同氏が 2 期（19641968, 1972-1976 ) 務めたほか，J.コストロヴィ ツキ（2 期）である。

しかしながら，1989 年以降，ポーランド地理 学界は市場経済への移行という社会経済体制の変 貌のなかで激動期をむかえ，新たな社会的役割を 果たすべく, 大学 (学部・学科) の名称変更, 研 究組織の再編成, 入学定員の増加, 新組織の創設 など目まぐるしい変貌を遂げつつある。

IG PAN や現在の IGiPZ PAN も社会主義時代 も含めてつねにその時々の課題に応えるべく, 研究 組織の再編成を続けてきた。そのため研究所内外 には研究組織の再編成は創立以来やっていない時 期はなかったと自嘲気味に指摘する研究者もいる。

3) 大学院・学部教育の問題一大学における地 理学研究・教育一

3-1) 大学の地理学科

2011 年現在, IGiPZ PAN と 11 大学および教 育系・経済系アカデミーなどで地理学の研究と教 
育がおこなわれている。地理学科は組織的には生 物・地球科学学部などの学部のなかに置かれてい ることが多い。独立した地理学部があるのはワル シャワとウッチの 2 大学だけである。地理学研 究の成果に対して「博士」(Doktor) および「上 級博士」(Doktor habilitacja) の学位を授与でき るのは 8 大学と IGiPZ PAN だけとなっている。

ポーランド全体では約 1,200 人の地理学者が研 究・教育職に就いている。うち教授・准教授は約 200 人と推定されている (Czyz, 2002)。

ポーランドにおける地理学研究は, なによりも ポーランド科学アカデミーに責任を負う上記の IGiPZ PAN，ならびにポーランド地理学協会の 枠組みのなかで大学（Uniwersytet）および同レ ベルの専科大学 (Akademia), たとえばワルシャ ワ経済大学，クラクフ教育大学，ポズナン経済大 学などで進められている。

ポーランドの大学は 5 年制が一般的で, 卒業 すると「修士」( $\mathrm{MSc})$ の資格を取得できる。ま た，ポーランドではヨーロッパの伝統に従って， 1 都市には 1 つの大学が存在し，他の高等教育機 関はアカデミアなどと称していた。ところが近年 の大学改革のなかで, 教育や経済の専科大学が 「大学」に昇格し，たとえばクラクフでは現在 3 つの大学 (ヤギェウォ大学, クラクフ経済大学, クラクフ教育大学) で地理学が研究・教育されて いる。

全国各地の大学などで地理学の研究と教育が行 われているが, 研究活動の面では, 首都ワルシャ ワと南部の中心都市クラクフが中心地である。前 者ではワルシャワ大学を中心にワルシャワ経済大 学, ワルシャワ工科大学でも地理学が講じられて いる。

$2 つ の$ 研究中心地についでポズナン（Adam Mickiewicz Univ.), ウッチ大学が続き, 以下, シロンスク大学 (Sosnowiec), ヴロツワフ大学, ルブリン大学 (Marie Skłodowska-Curie Univ.), シュチェチン大学，グダンスク大学，トルン大学 (Nicolaus Copernicus Univ.), ビドゴシュチ大 学 (Kazimierz Wielki Univ.) が各地の地理学研 究・教育のセンターとなっている。これらの大学
における地理学科は規模・分野・歴史・施設など で一様ではなくさまざまな特徴を擁している。

ここでは，大学における地理学研究を代表する ワルシャワ大学とヤギェウォ大学 (クラクフ) の 地理学科について紹介してみる。

\section{3-2）ワルシャワ大学（2011 年現在）}

ワルシャワ大学は 1818 年創設でポーランドで は古い大学であり，またポーランドを代表する大 規模な総合大学である。ただポーランドの大学生 の出身地の地域構成は, 多くの研究例によって明 らかにされていることであるが，ワルシャワ大学 といえども必ずしも全国各地から集まる学生で構 成されているわけではなく，首都ワルシャワのあ るマゾヴェツキ県を中心に北のヴァルミエ・マ ズール県，北東のポドラシェ県の範囲から進学す ることが多い。地方中心都市の大学が核となって その都市圈をこえて他の都市圈に学生が進学する ことは多くはない。

ワルシャワ大学は都市の起源となった旧市街 (Stare Miasto）から南に続く「王の道」と称す る大通り（ul. Krakowskie Przedmieście）に沿っ た段丘面に本拠地を構えてきた。しかし大学の規 模拡大とともに本キャンパスが手狭になってい た。近年，本キャンパスのある平地を下ったヴィ スワ左岸低地に新用地を確保し，中央図書館を核 とした新キャンパスで教育組織の再編成と再配置 を進めている。

地理学科に相当する「地理学・地域研究学部」 (Widział Geografii i Studiów Regionalnych UW) は，大学正門に隣接した古い 4 階建ての建物（ウ ルスキ宮）を占拠していた。この由緒ある建物に は，社会主義時代を通して半世紀にわたって IG UW と IG PAN が共存していた。市場経済体制 への移行後に, IGiPZ PANがようやく都心の中 央地区内に中層ビルを取得して転出したため, ワ ルシャワ大学地理学部の教育・研究環境がおおい に改善された。

ワルシャワ大学地理学部が改組された地理学・ 地域研究学部は, 教授 (Profs) 14 人, 准教授 (Dr. hab） 16 人，計 30 人，研究員 $(\mathrm{Dr}) 8$ 人，非常 勤講師 16 人を含めて 60 人以上の研究スタッフ 
を擁し, 間接部門も含めると総員 100 人規模と なり，これは全国大学のなかで最大の組織となっ ている。かつては行政部門や補助部門が実に充実 していたが，市場経済体制下で大学改革の名で合 理化が強行され, 学習環境の改善は進んでいな い。

地理学・地域研究を専攻する 1,300 人の学生お よび大学院生（Doktorant）が学んでいる。地理 学・地域研究学部の構成は, ジオエコロジー（地 生態学), 堆積学, 水文地理学の自然系にくわえ て, 社会経済・空間経営の地理学, 地域・グロー バル研究の 5 講座, および地図学と GIS 部門を もっている。また別のキャンパスに発展途上国の 学際研究施設（アフリカ研究，アジア・太平洋研 究）を運営している。

\section{3-3) ヤギェウォ大学 (クラクフ) (2010 年現在)} ヤギェウォ大学は 14 世紀中葉（1364 年）に カジミェシ三世によって創建されたポーランド最 古の大学であり, 中欧でもカレル大学 (プラハ) についで 2 番目に古い大学である。またクラク フは 17 世紀初頭にワルシャワに遷都するまで長 くポーランド王国の首都であったため, 長くガリ ツィア地方の文化と科学の中心地の役割を果たし てきた。

ヤギェウォ大学地理学・空間経営学科 (Instytut Geografii i Gospodarki Przestrzennej Uniwersytet Jagielloński, IGiGP UJ) は生物・地球 科学部に属する。クラクフは 130 年の歴史をも つポーランド最古の地理学の研究と教育の中心地 である。クラクフの市街地はワルシャワや多くの 都市とは異なって, 第二次世界大戦で深刻な戦禍 を免れたため, それまで地理学研究所は市街地に 蛸足状態だったのを, ヴァヴェル城下のヴィスワ 左岸の王家の武器庫跡に本拠を移し, 半世紀にわ たって地理学研究と教育の中心地として全国に覇 をとどろかせてきた。しかし由緒あるこの建物は 重要な歴史的建造物であるが, 老朽化と狭小さで 学習環境が悪化していた。

近年になって, クラクフ市南部の広大な植物園 のなかに新キャンパスと建物群を開発し, 教育研 究環境を著しく改善してきた。現在は地理学・空
間経営研究所との名称のもとで 9 つの大講座を 擁する組織に成長している。

自然地理学, 地形学, 土壤地理学, 水文学, 力 ルパティア山地の気候学, 人口・集落・農業地理 学, ツーリズム・リゾート経営の地理学, 地域発 展の地理学, それに GIS・リモートセンシング である。従来からの地理学研究の伝統的分野に加 えて, とくに巡礼の地理学研究が発展しており, 宗教地理学研究の中心地が形成されつつある。雑 誌 “Pielgrinus Cracoviensis” はこの分野の発展 に貢献している。

研究所の陣容は, 研究スタッフ全体で 90 人の 大所带で, 職階上の内訳は, 教授 10 人, 准教授 (Dr hab) 9 人, 上級研究員 $(D r) 35$ 人, 研究 員 36 人である。大学院生 (Doktorant) は現在 117 人が在籍している。全国的にみて紛れもなく 盛況である。

ポーランドでは大学院生という階層グループは 認定しにくい事情がある。大学の課程はふつう 5 年間で，修了すれば「Magister」マギステル（修 士, Msc）の称号を得られる。引き続き大学で研 鑽に励み研究者養成コースに入学するためには博 士課程の院生になるが，かれらをポーランド（や ロシア）では社会主義時代から「博士候補」 (Doktorant, ドクトラント) と称している。そこ では一斉授業や演習などの授業はない。指導教員 のチームの末端として他の研究員とともにチーム の研究課題に向けて研究補助の仕事を分担する。 なかには有給の任期制助手として講座の雑務一般 を担当するが，院生の全員がやるわけではない。

\section{3-4）その他の大学}

ポーランド中西部の大都市ポズナンにはアダム . ミツキェヴィチ名称総合大学とポズナン経済大学 に地理学科がある。ホイニッキ(Z. Chojnicki), チシュ (T. Czyz), ドマンスキ (R. Domański) ら はポーランド地理学を代表する高名な教授たち で, 経済地理学の理論的探求や広く基礎概念の探 求の分野で業績が高く評価されている（Chojnicki, 1979)。

全国大学の地理学教室のスタッフ数は無論日本 に比して多いし，ワルシャワやクラクフの大学に 
表 1 ポーランド主要大学の地理学教室の教員数 (2006).

Table 1 Number of teaching staff in universities having a department of geography in Poland (2006).

\begin{tabular}{|c|c|c|c|}
\hline 大学名（都市名） & 教授 & 准教授 & 講師・研究員・助手 \\
\hline ポーランド科学アカデミー地理学・空間経営研究所 (ワルシャワ) & 8 & 13 & 29 \\
\hline カジミェシ大王大学（ビドゴシュチ） & 3 & 5 & 8 \\
\hline グダンスク大学（グダンスク） & 2 & 6 & \\
\hline ヤギェオ大学（クラクフ） & 13 & 5 & 37 \\
\hline マリエ・スクウォドフスカークリェ大学（ルブリン） & 8 & 10 & 56 \\
\hline ウッチ大学（ウッチ） & 5 & 11 & 43 \\
\hline アダム・ミッキェヴィチ大学 (ポズナン) & 6 & 1 & 29 \\
\hline シロンスク大学（ソスノヴィェツ） & 6 & 12 & 53 \\
\hline ニコラス・コペルニクス大学 (トルン) & 10 & 7 & 36 \\
\hline ワルシャワ大学（ワルシャワ） & 13 & 19 & 67 \\
\hline ヴロツワフ大学 (ヴロツワフ) & 4 & 9 & 40 \\
\hline
\end{tabular}

ここでは「地理学教室」を, 学部 (Widzial, Fakultet), 研究所 (Instytut), 学科 (Department) などの総 称として用いることにする.

資料：“Informator Nauki Polskiej 2006”, Tom 2a, Instytucje Naukowe, Ośrodek Przetwarzania Informacji, Ministerstwo Nauki i Szkolnictwa Wyzszego, 2220p.

遜色のない人員を擁している（表 1 ）。これは全 国大学の地理学教室がとくに学部生の教育活動に 傾斜していて，地域の実態を反映した広い範囲の 研究に依拠した地理学教育が重視されているから であり, その成果は各大学で出版されている研究 報告書に反映されている。

強調しておきたいことは, 地理学研究の側面で こそ大学間地域間の格差は目立つが，地理学教育 の面では大学間の差異は小さく, それぞれの個性 を前面にだした教育で地域のニーズに応じた人材 を供給している。

これまでポーランドで大学といえば，それはス トレートに国立大学を意味していた。社会主義時 代, 唯一の私立大学はルブリンにあるカトリック 大学で，学生数はわずかであった。市場経済体制 の確立とともに，ポーランドにも国立ではない高 等教育を担う大学が多数出現している。その数は 確実に増加中である。

そのなかでただ一つ地理学部・学科を設置した のは「ビドゴシュチ経済高等学院」である。その 教育課程をみた。学部の名称は「ツーリズムと地 理学」で，2 講座からなる。一つは「地理学と空 間経営」, 他は「ッーリズム・ホテル学・美食学 (ガストロノミー)」とある。教員数も 28 人と充
実している。教員リストにはポズナンの高名な大 教授（故人）が載っていた。退職後の再就職口の ようだ。もっとも，ポーランドでは専任教員と非 常勤教員との差は小さく兼任禁止などの制約も少 ないから，講義などの義務さえこなせばほぼ専任 教員に近い収入が保証される。こうして，かなり の教員が複数の大学などに登録されている。

そうした新生の大学・学部・学科の名称や教育 内容には，これまでの伝統的な大学とは異なった 名称や講義名が付されていることが多い。なかに はおよそ学問体系などとの関連性が想像できない ほど乘離している新設大学も少なくない。専門学 校で習得する単なる技能の習得を専らとする教育 機関に大学という名称が冠せられているのはいま や洋の東西を問わず共通している。地理学もここ まで「現代化」すれば危機を克服できるというの であろうか。

\section{4) 中等教育における地理教育の問題}

1989 年, ポーランドは長く続いてきた初等中 等教育を,八・四制から六・三・三制に変更し た。第二次世界大戦後のポーランドで「地理」は 「歴史」とともに終始独立した教科として存在し ていたし現在も存在し続けている。その意味で体 制転換との関連性はほとんどない。社会主義時代 
もその以前もその以後も, 地理は一貫して独立教 科である。

その背景にはヨーロッパにおけるポーランドの 地政学的位置の重要性, および国土・国家・国 民・近隣国家との関係について学ぶ「地理」の重 要性について国民的に共通理解が存在しているこ とがある。ポーランドにおいて地理と地理学が強 固な基盤をもっていると指摘したことの証左でも ある。

その理由として次の 3 点が指摘できる。(1)上 述の通り科学としての地理学の地位が高いこと。 (2)アメリカ型の社会科（Social Studies）の伝統 と影響力が弱いこと。生活視点の市民教育は地理 や歴史とは別の教科となっている。社会主義時代 自体がこの伝統を維持する防護壁の役割を果たし ていた。これらの事情は近隣する東中欧諸国にも 通じる点が多い。

教科書検定は教育省内に設置される教科書委員 会があたる。委員会はおもに地理学者が中心的役 割を果たし，教育省担当者は領土・歴史問題の記 述に関心をもつが，その他の内容は委員会の自由 裁量となっている。(3)注目すべきは，日本の学習 指導要領（とその解説書）などの一律化装置が存 在せず，教育行政は理念・原則・基準を提示する にとどめていることである。社会主義時代にも教 科書編集においてイデオロギッシュな強圧指導は 少なく, 研究者主導の自由な教科書編集が進めら れていた。逆に日本の地理教育にみるように，学 習指導要領体制下で一言一句の解釈権の独占をて こにした指導で関係者を右往左往させることはな い。

ポーランドの中等教育における地理は,「地理 教育」ではなく「地理学教育」である。ここで言 う地理教育とは児童生徒の地理的認識を成長発展 させるための教育で，視点を学習者にあてて組み 上げていく学習体系であるのに対して，地理学教 育は地理学研究の到達点に立って，その成果を教 育的に組みほぐしていく学習体系である。両者は 相対立する逆方向べクトルであって，目的も方法 も相容れない関係にある。ポーランドでは前期中 等教育から高等教育まで地理学研究の成果や到達
点が整理され一貫性のある内容となっている。

教科書にはそれが見事に反映されている。前期 中等教育地理の最新の教科書は文献の通りである が，そこには地理の基本内容が客観的に整然と整 理されている (Malarz, 2009)。また 3 分冊の教 科書それぞれにDVD 教材が付属していて，教科 書の補足説明や演習課題などが付加されている。

\section{III. 学術的に特色がある研究分野，世界的な 地理学者, 日本との研究交流}

\section{1）特色ある分野，学術的に価値が高い研究}

ポーランドの人文地理学研究における特色ある 分野および学術的に価值が高いと思われる研究分 野として，つぎの $5 つ の$ 分野に集約することが できる。

第一の分野は, 経済地理学の基礎理論の探求・ 構築に関わる分野である。1950 年代後半から 1970 年ころにかけて，ポーランド地理学の主唱 によって IGU 内にコミッションが組織され，そ こでの研究成果が国際的に高く評価されている。 この潮流は広くはソ連におけるモスクワ大学・レ ニングラード大学（当時）を拠点とした経済地理 学の基礎理論の探求と創造に触発されたもので, 国土の社会主義的発展と関連させていた。モスク ワ大学のヴェ・ア・アヌーチン「地理学の諸問 題」（1960）が代表的な業績である。

東中欧ではポーランドとともにチェコスロヴァ キアとハンガリーでも科学アカデミーを拠点に多 くの報告書が公刊されている（Leszczycki, 1961; Dziewoński, 1962; Macka, 1967)。おもに経済地 域区分に関連する理論探求の分野である。この研 究は第二次世界大戦後の比較的早い時期に始期を たどることができ，1950 年代後半から 1970 年 代にかけておもにIG PANを中心に推進された。 経済地域の概念，経済地域区分論，国土の空間構 造の解明などが活発に議論された（Fleszar and Leszczycki, 1970)。

この流れはまぎれもなくポーランド国土におけ る社会主義建設の諸課題と連動する実践的な課題 として経済地理学分野からの貢献が意識されての ことであり，それゆえに国家的レベルでバック 
アップされていた。

当時のポーランド地理学界で大きな影響力を発 揮していたレシチッキを中心に，若手の故ヴルー ベル (A. Wróbel), ポズナンのホイニッキ (Z. Chojnicki）などが IGU の大会やコミッションで 活躍した。日本からは故鴨澤 嚴が参加してい る。

経済地理学の理論探求の試みは当時の地理学界 でもそれと並行して進展していたが，ともに実際 の経済建設と結合しており，あくまでもアカデミ ズム内での論争に終始した。けだし卑俗な実用主 義に埋没することなく, 真摰に探求されていたこ とが, 市場経済時代に移行した後も地理学の権威 を維持させる要因につながった。とくにポーラン ドの場合は戦後 50 年間に三度の地方行政制度の 再編成を経験しているが，その過程でこうした研 究成果がとり込まれている。

第二に, 都市・人口地理学の分野における研究 成果である。ポーランドの都市地理研究は早い時 期から欧米の都市地理学の発展に刺激を受けつつ も独自の研究発展の足跡を示してきた。とくにレ シチッキらと同世代の故ジェヴォンスキ（K. Dziewoński）を核として，その後継者で長く地理 学研究所の所長を務めたコルツェリ (P. Korcelli), さらにヴェンッワヴォヴィチ (G. Węcławowicz) へと続き, IGiPZ PANの人文地理学の主流とし て今なお研究者育成の中心の役割を果たしてい る。コルツェリらはミネソタ大学でアメリカの都 市研究者との交流を通して大都市圈の発展モデル を進化させてきた（Korcelli et al., 2008）。

ヴェンツワヴォヴィチらの首都ワルシャワの都 市地理研究は, ワルシャワ大都市圈研究に優れた 業績をあげてきたし，実証精神にあふれた実態調 査で社会的に注目されている。その成果は不定期 刊のシリーズ “Atlas Warszawa”に続々と発表 され, 活気のある研究チームが内外からの人材を 引き付ける原動力となっている（Węcławowicz et al., 2006)。

三つ目には，国民経済の空間構造研究から派生 した潮流とも位置づけられるが，社会主義時代の 国土の計画的発展と結びついて，1980 年代以降
に社会主義型未来学（Socialist Futurology）と もいうべき研究成果が開花した。

その中心にあったのはククリンスキ (A. Kukliński, ワルシャワ大学, 当時) の研究グループで ある。かれらはオランダ, イタリア，フランスな どの地域科学研究者の協力を得て「国連社会発展 研究所」(United Nations Research Institute for Social Development, UNRISD) のプロジェクト 研究を組織し, その成果は Kukliński（1972）を 含む一連の叢書に結実している。その過程で極形 成論 (Growth Pole Theory) や地域科学の発展に 貢献している。

さらに市場経済への移行，ポーランドの EU 加 盟が日程に上るとともに，EU 空間のインフラ整 備と随伴して，ロンドン・パリ・モスクワを結ぶ ヨーロッパ新空間の構築を提唱するなど新たな展 開をみせている（Kukliński, 2003）。

第四に, IGiPZ PAN におけるョーロッパ地理 学の伝統を継承する地域地理学の潮流である。こ れはワルシャワ大学地理学・地域研究学部とも共 通する面が多いが，社会主義時代には国民の政治 教育とも連携しながらアカデミー以外の教育機関 (ポーランド統一労働者党大学校) などでバルバ ク (B. Barbag)，ヴィニド (B. Winid)（ともに ワルシャワ大学)らを中心に活発に論陣を張った。

IGiPZ PAN ではこの流れは 1960 年代にはクク リンスキ，70 年代にはマリシュ（B. Marisz）が 主宰したが, 後に発展途上国研究の成果も統合し て故ロシチシェフスキ（M.M. Rosciszewski）の 「発展の地理学」(Geography of Development) に受け継がれ，その後は，エベルハルト（P. Eberhardt, 1935-2005), さらに 2006 年以降は若手 のコモルニッキ (P. Komornicki) に受け継がれ ている。前者の業績の集大成というべき『20世 紀の中東欧における民族と人口の変化』（Eberhardt, 2001）はいまなお圧巻である。

コモルニツキらは EU 加盟後のポーランドにお ける東部国境問題に注目し，実態調査を重ねてい る (Kitowski, 2003, 2010; Komornicki, 2010)。 その延長で東中欧諸国の地理学者を招いて “Warsaw Regional Forum”（2004 年第 1 回開催, 隔年 
開催）を開催している（Degórski, 2006）

英語による学術誌“Geopolitical Studies”は IGiPZ PAN の代表的な刊行物であるが，その成 果はこの潮流の活動によっており，同時に地域地 理学研究の現代化という側面をもっていることに も注目したい。

第五には，ポーランドの地図製作の分野での業 績である。中欧諸国には多かれ少なかれ地図製作 の伝統が強いが，ポーランドもそうした国の一つ である。新生ポーランド時には軍事と結んだ測 地・地図製作が実施されてはいるが，大学などの アカデミズムでも地図製作部門は地理学研究と密 接に連携して，重要な柱となっている。

社会主義時代, ナショナル・アトラスは, IG UW と IG PAN が共同で製作していたが，現在 は施設と技術陣ともども IGiPZ PAN の業務と なっている。これまでに二度，ポーランドのナ ショナル・アトラスの作成と刊行の過程を垣間み た。最初は「国際地図年」に標準をあわせて出版 された “Narodowy Atlas Polski”（ポーランド国 家アトラス, 1973, 185p.) であり，近くは“Atlas Rzeczypospolitej Polskiej” (ポーランド共和国ア トラス, 1993, IGiPZ PAN)，であった。何度かの 滞在中に “Atlas Przemystu Polski”（ポーランド 工業アトラス, 1975, Red.: Stanisław Leszczycki, IG PAN, 85 sheets）の存在を知った。

地図は一面では軍事と関連が深い。社会主義時 代には地形図（5万分の 1) は入手ができなかっ た。また閲覧は不可能ではないが，閲覧許可を得 るためには実に煩雑な手続きが不可欠だった。ま た私蔵の『ポーランド工業アトラス』(1975 年) には丸秘（“Poufny”）の印が押され，配布番号が 書き添えられている。1990年代になってようや く主著者の M 教授から開示され贈呈された一本 である。

\section{2) ポーランドとの研究交流}

日本とポーランドとの研究交流について触れ る。1960 年代初期, 日本が IGC に参加するよう になって, 国際会議などでポーランド地理学者と コンタクトが生まれ，研究交流がはじまった。当 時, IGCに出席された世代は多田文雄, 木内信蔵,
青野壽郎らであろう。その後, IGU 傘下のコミッ ションや招待交流などで, 関口 武, 鴨澤 嚴, 吉野正敏, 中村泰三, 山口岳志, 大矢雅彦などが ポーランドを訪問し研究交流の機会をもった。 1980 年 IGC 東京大会の開催でポーランドから地 理学者が多数訪日し, 多角的飛躍的に交流機会が 増大した。しかし若い研究者・院生などの留学デ スティネーションとしてポーランドが選択される ことはなかった。おそらく野原敏雄や山本 茂ら が最初ではないか。

東欧革命後，東欧諸国の調査環境の変化のなか で小林浩二を中心に研究グループが組織され, 数 年間にわたって東中欧を対象地域としたエクステ ンシヴ調査が行われ, 多くの出版物や報告書が公 刊されている（例えば, 小林ほか, 2000）。

これまでの日ポ間の交流は個人単位であった が, 組織的な研究交流の㜴矢は,「日本ポーラン ド地理学セミナー」で過去 4 回実施されている。 このセミナーは小規模なバイラテラルな交流であ るが，1987 年以来数年おきに 4 回（ポーランド で 2 回, 日本で 2 回 (都留市, 名古屋市)) 開催 されている。その後も長くポーランド科学アカデ ミーから開催の督促を受けていたが，資金と組織 者の不足で中断してしまった。

\section{IV. 将来展 望}

著者は冒頭でポーランドの地理学と地理教育は 安定的であり基盤はしっかりしている，それは日 本の状況とは対照的であると述べた。しかし, ポーランドの地理学や地理教育が近 20 年にわ たって, 激動にさらされ続けていることも事実で ある。東欧革命直後, とくに科学アカデミー制度 は社会主義時代の遺物とみなされ, 若くて有能な 多くの研究者が他国の大学にポストを得たり転 職・転業していった。最大の危機はこの時期で あった。

その後の地理学界は市場経済体制下で国民の負 託に応える研究のあり方とはどうあるべきかにつ いて真摰な検討を深め, 次第にかつてのような自 信をとり戻しつつあるように思われる。問題は大 学教育の側にあって, 大学進学率の上昇とともに 
教育内容を刷新し調整していくという，いわば日 本の現実とほぼ同一の問題に直面している。地理 学研究の課題は, 若い優秀な人材の確保であり, 新たな研究資源の創造，さらには国家政策へのコ ミットの強化の三点であろう。

\section{謝 辞}

本稿を作成するにあたって, 資料と討論の機会を 提供された 3 人の地理学者, Prof. dr hab. Zbigniew Taylor, Prof. dr hab. Grzegorz Węcławowicz (ともに IGiPZ PAN), 村山祐司 (筑波大学) の諸兄に深甚な謝 意を表すものである。本稿を草するため，故鴨澤 嚴 教授遺贈資料のうち 3 点の文献を利用させていただい た。ここに記して感謝を申し上げたい。

\section{文献}

Chojnicki, Z. (1979): The methodological bases of prediction in Economic geography. Quaestiones Geographicae, 5, 23-34.

Chojnicki, Z. ed. (1996): Contemporary Problems of Polish Geography. Bogucki Scientific Publishers.

Czyz, T. (2002): Rozwoj kadry naukowo-dydaktycznej geografów i powiazania ośrodków akademickich w procesie jej kształcenia w Polsce w latach 19902000. Przegtad Geograficzny, 74(1), 3-27.

Degórski, M. ed. (2006): Natural and Human Environment of Poland: A Geographical Overview. IGiPZ PAN.

Dziewoński,K. ed. (1962): "Economic Regionalization", Materials of the First General Meeting of the Commission Held in Utrecht, the Netherlands, Sept. 1961. IG PAN, "Dokumentacja Geograficzna", Zeszyt 1.

Eberhardt, P. (2001): Ethnic Groups and Population Changes in Twentieth-Century Central-Eastern Europe. Sharpe.

Fleszar, M. and Leszczycki, S. (1970): Spatial Structure of Poland's Economy. IGKR.

Jackowski, A., Liszewski, S. and Richling, A. eds. (2008): Historia Geografii Polskiej. PWN.

Kitowski, J. ed. (2003): Eastern Dimension of European Union. IGiPZ PAN. (Geopolitical Studies, 11).

Kitowski, J. ed. (2010): 20 Years of Socio-economic Transformations in Countries of Central and Eastern Europe: An Attempt of Accounts. IGiPZ PAN. (Geopolitical Studies, 16).

小林浩二 - 佐々木 博 - 森 和紀 - 加賀美雅弘 - 山本 充・中川聡史・吳羽正昭共編 (2000): 東欧革命後の
中央ヨーロッパー旧東ドイツ・ポーランド・チェコ・ スロヴァキア・ハンガリーの挑戦一。宮書店. [Kobayashi, K., Sasaki, H., Mori, K., Kagami, M., Yamamoto, M., Nakagawa, S. and Kureha, M. eds. (2000): Central Europe after the East European Revolution: Challenges in the Former East Germany, Poland, Czechia, Slovakia and Hungary (Too Kakumeigo No Chuo Yoroppa). Ninomiya Publisher. (in Japanese with English title) *]

Komornicki, T. (2010): Flows of persons and goods across the Polish segment of the outer boundary of the European Union: Results of a research project. EURO XXI, 20, 9-29.

Korcelli, P., Korcelli-Olejniczak, E. and Kozubek, E. (2008): Typologies of European urban-rural regions: A review and assessment. Geographia Polonica, 81 (2), 25-42.

Kortus, B. (2001): Z historii rozwoju instytucjonalnego geografii polskiej. Czasopismo Geograficzne, 72(3/4), 245-258.

Kukliński, A. ed. (1972): Growth Poles and Growth Centres in Regional Planning. Mouton.

Kukliński, A. (2003): Towards a new European space: The trajectory London-Paris-Moscow, a memorandum. EUROPA XXI, 8, 5-14.

Leszczycki, S. ed. (1961): "Problems of Economic Region", Paper of the Economic Regionalization in Kazimierz (Poland), May, 1959. IG PAN. (Geographical Studies, No. 27).

Macka, M. ed. (1967): "Economic Regionalization", Proceedings of the $4^{\text {th }}$ General Meeting of the Commission on Methods of Economic Regionalization of the IGU, 1965 in Brno (Czechoslovakia).

Malarz, R. ed. (2009): Puls Ziemi, Podręcznik do geografii dla klasy pierwszej gimnazjum, Tom 1-3. Nowa Era.

Rykiel, Z. (1988): The functioning and the development of Polish human geography. Progress in $\mathrm{Hu}$ man Geography, 12, 391-408.

Taylor, Z. (1985): Geography as an academic discipline. Journal of Geography in Higher Education, $9,9$.

Węcławowicz, G., Bański, J., Degórski, M., Komornicki, T., Korcelli, P. and Sleszynski, P. (2006): Przestrzennie Zagospodarowanie Polski Na Poczatku XXI Wieku. IGiPZ PAN. (Monografie, 6).

Zioło, Z. ed. (2010): Procesy transformacji przemystu $i$ ustug $w$ regionalnych $i$ krajowych uktadach przestrzenych. Wydawnictwo Naukowe UP Kraków. (Prace Komisji Geografii Przemystu PTG, Nr. 15) .

* Title etc. translated by S.Y.

(2012 年 2 月 29 日受付, 2012 年 6 月 13 日受理) 